DÁNIEL DEÁK ${ }^{*}$

\title{
Taxation of the Financial Sector: Regulatory and Justification Issues
}

\begin{abstract}
The so-called bank levy-a tax levied on bank leverage-has been proliferated to date. They are the product of reacting to the global financial crisis that started in the autumn of 2008 . Therefore, they can only be understood in the context of the crisis. Since one or two decades, the financial industry has produced much innovation that is to be reflected in taxation. The application of bank levy is thus the result of the reforms initiated in the sphere of financial regulation rather than tax law. Financial and tax laws are different from each other in many respects, however, as it will be discussed below where the constitutional background for the introduction of financial taxes will be explored. In this paper, bank levies; one of the newly introduced financial taxes-are in the centre of interest. In this respect, the paper concerns detailed policy matters and justification issues.
\end{abstract}

Keywords: bank leverage taxation, excessive finance, tax incidence

\section{Regulatory policy issues in detail}

A bank leverage tax is a levy that is designed to influence how much financial enterprises should be leveraged. The idea of introducing such a tax is to deter banks from getting engaged in excessive financial activities. ${ }^{1}$ From the viewpoint of legal regulation, it is therefore a key issue of how to identify excessive financing. This question will be discussed later. Before, it is important to get familiar with the functions this tax is expected to fulfil in the regulation of the conduct of the participants of the financial market.

\section{(i) Tax and non-tax tools of regulation, steering duties}

In general, the functions of taxation are:

- to raise funds for public purposes;

- to contribute to economic stabilisation; and

- to administer distributive justice.

With a bank levy, the function of economic stabilisation can be highlighted.

While special financial taxes can be considered as tax related regulatory tools, they can also be seen in parallel to non-tax regulatory tools (in German-speaking literature: "ordnungsrechtliche Maßnahmen"). ${ }^{2}$ The bank levy as a tax related regulatory tool can be compared to the Basle standards as non-tax regulatory tools. Taxes operate as the means of social control in all times, even if this function is usually secondary to the function of

* Professor of Law, Corvinus University of Budapest, H-1093 Budapest, Fővám tér 8.

E-mail: daniel.deak@uni-corvinus.hu

${ }^{1}$ More broadly, a bank leverage tax is a Pigovian one, the function of which is to alter prices, so as to better align private decision-making with wider economic and social considerations. See: Keen, M.: The taxation and regulation of financial institutions, Colloquium on tax policy and public finance. New York, 2011. 10.

2 Bergfeld, K.: Lenkungsabgaben im europäischen Finanzrecht. Baden-Baden, 2008. 17-18, 25, 27, 30 . 
raising money. In comparison to taxes, there are other types of social control as well. The latter are designed directly to influence the social conduct under certain circumstances. A bank levy can be characterised by referring to a combination of the functions of fundraising and social control. More precisely, in case of bank levies, the function of fundraising is superseded by that of social control. With normal taxes, this is inversely, i.e. the function of social control is subordinated to that of fund-raising. As, in case of a bank levy, the function of social control takes precedence to that of collecting money, it constitutes an example for charges that can be considered as para fiscal charges or steering duties (in German-speaking literature: "Lenkungsabgaben"). The effective German bank levy (Bankenabgabe) is a good example for this.

Steering duties as mentioned here, and corrective taxes that have been discussed above are the same phenomena. They all are para fiscal charges, meaning that their function is not just to raise funds, but also to seek to influence the taxpayer's behaviour, and to orient them in a way a regulatory power considers desirable for macroeconomic purposes. In case of corrective taxes, it is highlighted that they are adjusted to the estimated macroeconomic harm to be eliminated by way of taxes. In case of steering duties, a particular type of social control is singled out. Hence, the former term focuses on the function, the latter one on the structure of the tax related tools of legal regulation.

Tax and non-tax tools of social control must be examined on a comparative basis. The instances of comparison can be highlighted as follows: ${ }^{3}$

- Incidence-i.e. who bears the real incidence of regulation and taxes in the financial sector?

- Perimeter-i.e. the set of firms to be taxed or regulated needs to be defined when designing the scope of taxes or prudential rules.

- Calibration-i.e. determining the appropriate corrective actions requires understanding how the financial sector will respond to policy, and deciding how large the relevant externalities are.

A bank levy can be characterised by three features:

- They fulfil the function of exercising influence on the social conduct.

- They are established on a link existing between the liability to pay and the receipt of public services. They can be considered in this respect to "Kausalabgaben", i.e. to public charges that are compensated by the provision of public services. In case of a bank levy, it can still be problematic to interpret this link between the liability to pay for the public and the receipt of public services. Truly, it is in the public interest-and in the best interests of financial service-providers-to identify and isolate systemic risks. The money collected from bank levies is still not spent directly and exclusively on banks. In this respect, it is difficult to justify such a levy as a sort of "Kausalabgaben".

- The constitutional basis for introducing bank levies is not necessarily independent. National public authorities usually need special authority to levy steering duties. This may also be a problem for the introduction of FTT at a European level, the revenue of which should be collected to go to the own EU sources. In order to reach this goal, it is necessary, however, to authorise the EU to introduce a new category of own resources in accordance with Article 311 TFEU. ${ }^{4}$

${ }^{3}$ A fair and substantial contribution by the financial sector, IMF final report for the G-20, June 2010. 52.

${ }^{4} \operatorname{COM}(2011) 510$ final. 
Reflexivity can be realised not only in financial innovations (where the pricing of fundamental goods can be dramatically affected by the movements of the financial market), but law related social organisation can also be filled by reflexivity. Reflexive law does not rely on either formal, or substantive rationality. Instead, social control to be negotiated by this type of law is based on self-regulation, and on the recursively determined forms of social cooperation that can be developed on a micro-scale. For instance, communities of consumers can organise themselves to achieve their effective protection at a sufficient level. This is to complement statutory law regulation that concerns the major mechanism of the official society. Such micro-scale communities can be organised, based on bargaining, participatory democracy and consistency of the values that are developed through a process of discourse. In the tax law area, contracting out makes an alternative to the standard vertical relationship of taxpayers and the tax authorities. This makes it possible-for example, for the so-called qualified financial intermediaries that can act as authorised economic operators before the public authorities by way of contracting-to enforce the tax law rights and obligations in a horizontal way.

The law of such contracts is different from normal statutory law. It can only be interpreted as the product of reflexive law. This is to replace, or rather complement, both the perfection of individualism in line with conceptually constructed rules to be applied through deductive logic, and the collective regulation of economic and social activity through the purposive programmes of action to be implemented via regulations. The basic functions of reflexive law are self-reproduction and constant communication with the environment of the system of reflexive law through internal discourse and external coordination, respectively. Reflexive law is helpful with the management of social conflicts by making non-legal problems legal, while law as a system will also be influenced by its non-legal environment and abandons using categorical and comprehensive forms of statutory law. The key to functioning of reflexive law is procedural orientation where institutional structures and decision processes are relationally oriented. ${ }^{5}$ That is, parties are willing to seek to reformulate their mutual expectations that can fill the room for actions in concert from case to case.

It is not only in the economic life that goods are valued, depending on how much they can be shared with those to whom they are provided. It is also true in the sphere of public administration that specific rights and obligations concerning the conduct of taxpayers and tax authorities will be determined in relation to each other. This is to complement statutory law that cannot guide parties in sufficient details.

The gaps of the legal infrastructure that are developed in the financial sector are hoped to be filled by the reflexivity of law. Although parties may lack sufficient legal quality, they may be in cooperation with each other. The result of reaching agreements can be achieved by self-reproduction and constant communication with the environment on a micro scale through internal discourse and external coordination to be conducted among the market players. For example, the Hungarian Banking Association and the Government were able to arrive at an agreement in December 2011 on the crisis taxes to be introduced abruptly in the banking sector, as mentioned.

Steering duties are able to soften the harsh consequences of either normal taxes or non-tax regulatory tools. Although they lack a higher level of legal certainty, they can survive, based on the values mutually recognised from case to case. Mutual trust and 
adjustment to be shown to each other by parties are a driving force of this type of legal regulation. This is a form of social control that cannot be spared because it is otherwise difficult to identify the impact of the externalities that arise from the systemic risks to be associated with the financial operation. Bottom-up conflict management comes first in this respect, rather than comprehensive mandatory legislation.

The externalities to be addressed by a bank levy cannot be identified, based on comprehensive and unambiguous values that are determined preliminarily. In case of steering duties, including a bank levy, the traditional form of statutory law ends. This is because the externalities to be addressed cannot be approached, but by estimation. Estimates and rough calculation are not the same as precise and individually separable legal consequences, however. The question is of special interest in case of taxes-and the bank levy is a kind of tax-where the liability to pay should be established on legal precision. Under these circumstances, legal certainty cannot be fully guaranteed, or at least not in the traditional way. Instead, a kind of flexibility and adjustment is necessary. The addressee of the levy should accept what is levied even if the conditions of levy are specified subsequent to the taxable event only. Consensus cannot be reached in such cases, but during a process of discourse, in which the mutual expectations of parties-whether plainly spoken or notcan hopefully be met.

\section{(ii) Identification of excessive financing}

The control tool of bank levy can only be effective if excessive financing-that what is to be addressed by the levy-can be approximated. In this respect, it is crucial to distinguish between core and non-core liabilities of market participants. Core liabilities are the claims of the ultimate creditors (the household sector) on the intermediary sector, being on the verge of the financial system, making en entry into the real economy from the financial economy. A non-core liabilities tax is a prudential tool to dampen pro-cyclicality, making non-core funding more expensive. ${ }^{6}$

The notion of excessive financing can be approached, first regarding the distinction between speculation and enterprise as introduced already by Keynes in the way as follows. For purposes of short-term asset trading, the fundamental value of assets, based on the riskadjusted present value of expected long-term cash flows, may matter less than what average opinion expects the average opinion regarding resale value to be. ${ }^{7}$ Forecasting the prospective yields of assets over their lifetime can thus be contrasted to the psychology of market. One can refer here to what was mentioned about the principles that govern the market of financial innovation, from which the global financial crisis arises. This is the principles of reflexivity, virtualisation and self-generation (autopoiesis). The market schemes of financial innovation result in reflexivity in pricing, in amplification of realities due to restructuring of claims, and in growth stimulated by self-generation without sober limits. It comes therefore that volatility, non-transparency and liquidity problems cannot be escaped what triggers systemic risks. This is what must be addressed by a steering duty like a bank levy.

6 Shin, H. S.: Policy Memorandum on Non-Core Liabilities Tax as a Tool for Prudential Regulation (manuscript). Seoul, 19 February 2010, 7-8.

7 Shaviro, D.: The Financial Transactions Tax Versus (?) the Financial Activities Tax. New York, 2012. 4; Keynes, J. M.: The General Theory of Employment, Interest, and Money. San Diego, 1964 ed., 158. 
While approximating the scope of a bank leverage tax, speculation as such cannot be associated with externalities. Tax is rather addressed to hyper-speculation that can also be explained from a business ethics perspective. It is noteworthy ${ }^{8}$ that

- even if the question cannot be answered on what scale wagering on derivatives should take place, the question cannot be eliminated;

- it is common in excessive speculation on derivatives and tax planning that what is rational for the individual's private economy is not rational for the economy as a whole;

- distinction must be made between knowledge-enlarging and chance-driven wagers; the former constitute a value-creating component of the capitalist economy, the latter does not; and

- financial wagers on derivatives provide economic functionality insofar as they contribute to value-creation, such as hedging, market liquidity or arbitrage-excessive wagering on derivatives suppresses value-creating activities.

It is possible to give positive meaning to the subject of a bank leverage tax if one refers not only to the increase of financial stability, but also to the requirement that this tax should serve the finance of the common goods, even on a global level. The actual meaning of the common goods is, however, different in different circumstances, as this is only a framework term that must be specified from case to case.

Particular dangers of excessive financing can be enhanced after the sub-prime mortgage crisis as follows: ${ }^{9}$

- although securitisation is necessary, in order to benefit from financial innovation, the originate and distribute model is dangerous, and the claim for a fee instead of the deposit interest escapes the Basle standards;

- it is dangerous that structured investment vehicles as off balance sheet entities are sponsored by banks, but not owned (banks become bankruptcy remote);

- mark-to-market accounting may cause financial instability; and

- the tranching system of repackaged claims may cause opacity of risks in financial products.

Along with instability and opacity, the threat of excessive financing on the whole economy can further be explained. Although this explanation is provided in the context of introducing a Tobin-like tax (a transaction tax), the externalities to be hit are the same in case of a bank leverage tax. The comments as follows require particular attention in this respect: ${ }^{10}$

- financial transactions have expanded several times faster than transactions in the "underlying" markets for goods and services;

- trading in derivatives markets has expanded significantly stronger than trading in spot markets; and

- abrupt fluctuation in prices is the result of the accumulation of short-term (intra-day) runs, which persist in one direction longer than the counter-movements, i.e. in a "bullish"

8 Koslowski, P: The Ethics of Banking; Conclusions from the Financial Crisis. Dordrecht, 2011, Chapter 6: The Ethical Economy of the Market for Derivatives: Trading with Values Derived from Other Values for Hedging, Speculation, and Arbitrage, 94-95.

${ }^{9}$ Dam, K. W.: The Subprime Crisis and Financial Regulation: An International Perspective. J. Straus, J. (ed.): The Role of Law and Ethics in the Globalized Economy. Berlin, Heidelberg, 2009. 98-101.

10 Schulmeister, S.-Schratzenstaller, M.-Picek, O.: A General Financial Transaction Tax Motives. Revenues, Feasibility and Effects. WIFO, Vienna, March 2008, 1-3. 
market; upward runs persist longer than downward runs, the opposite is true in a "bearish" market.

Furthermore, according to Stephan Schulmeister, ${ }^{11}$

- both the IMF and EC proposals (as reflected in the respective 2010 working papers) are based on the false presupposition that markets tend to equilibrium, and departure from it is at random only;

- the bank levies as introduced seem to be less efficient insofar as they are targeted at holding, and not at trading in, assets; and

- the impact on the economy of the trade in derivatives and other structured financial instruments is significant not only due to its huge volume, but also because of its extremely high speed, and because notional contracts and high leverage have been enormously proliferated.

\section{(iii) Taxation of the holding of, versus trading in, securities}

Even if both a bank levy and a Tobin-like tax are aimed at the same subject, they are clearly different in their methodology. The point to this is that a bank leverage tax only concerns holding of securities, not trading in them. However, one can argue that a bank leverage tax can be as much efficient as a Tobin tax if certain conditions are met:

- it is dedicated to a special national fund;

- innocent assets or liabilities are excluded from taxation (low-risk assets, long-term deposits, etc.); and

- there is progression in taxation.

Further on, in case of a bank leverage tax, there is much less danger of relocation. In contrast to a Tobin tax, a bank leverage tax is based on the personal scope of taxation. Also, there is less possibility for the taxpayer to pass over the burden of tax to the client. It is the backside of the application of a bank leverage tax, however, that it is not able to meet a high standard of legal certainty and, insofar as it is normally dedicated to a special fund, it suggests also a challenge to the sovereignty, unity and completeness of the state budget.

Truly, as a bank leverage tax is a special tax, it is difficult to find a place for it in the legal system. In particular, it may challenge the equality principle insofar as it lays a special burden to financial service-providers. The legitimacy problem of legal certainty can also be raised, although it can be managed, provided that the legislator provides a comprehensive and detailed specification of legislative goals and determines homogeneous groups that can be described by their systemic relevance. In other words, if the law on a bank levy is specific enough, the equality problem can be escaped. The compatibility issue will thus not appear in case of a well-tailored tax law. As it can be seen from the German bank levy, it was the legislator's major concern to identify the scope of tax by well-prepared legislative goals. $^{12}$

The bank leverage tax ("BLT") is often compared to the options of an FTT and similar taxes, e.g. a securities transaction tax ("STT"). There are authors who criticise the option of

11 Schulmeister, S.: Austrian Institute of Economic Research (WIFO), Bank levy versus transactions tax: A critical analysis of the IMF and EC reports on financial sector taxation. WIFO paper, Wien, 30 April 2010, 1-3.

12 Schön, W.-Hellgardt, A.-Osterloh-Konrad, Ch.: Rechtsgutachten zur verfassungsrechtlichen Bewertung einer Bankenabgabe nach dem Regierungsentwurf eines Restrukturierungsgesetzes. München, 12. 10. 2010, 114. 
FTT, but who are in favour of BLT. An example for this can be shown in Table 1. In this respect, one can argue that it is realistic to expect that the risk of both relocation and nonrelocation avoidance can be significantly reduced. Also, the distorting effect of BLT could be below average. It is recommended to apply a wide taxable basis and rates that are below $0.1 \%$. Then, taxpayers would arguably not deem it necessary to look for substitute markets.

Table 1: Evaluation of the policy options of Bank Leverage Tax, Financial Activity Tax and Securities Transaction Tax ${ }^{13}$

\begin{tabular}{|l|l|l|l|}
\hline & BLT & FAT & STT \\
\hline Risk reduction & Potentially significant & Potentially significant & Insignificant \\
\hline Distortion & Below average & Below average & Above average \\
\hline
\end{tabular}

\section{Double charging of bank levy}

It is a particular feature of bank leverage taxes that they are based on the personal scope of taxation. As discussed, this results in double charging because both the foreign branches of domestic financial enterprises and the domestically operating branches of foreign financial enterprises are taxable. The scope of taxation is closely connected with the choice of connecting factors. While introducing a bank leverage tax on the model of the IMF FSC, all participants of the financial market may be caught by taxation that are authorised to provide financial services within a particular jurisdiction. Another important factor of taxationsimilar to the first one-is that all assets and liabilities that are included in the accounts of domestic resident financial enterprises are taxable. The choice of the financial and accounting law framework suggests not only worldwide taxation, but also expands the list of those to whom tax law is addressed. It comes from the usual perspective of both financial and accounting law that regulation is applicable to groups. This does not necessarily correspond with the logic of tax law, as discussed.

From the viewpoint of both financial and accounting law, it is normal that branches are included in the uniform treatment as dictated by domestic law. This is why in double bank levy conventions the taxation power rests with the state of origin even in case of branches, and it is only the residual taxation power that remains for the destination country. It also comes from this structure that it is the destination country (the host country) that will under treaty be obliged to give credit, and it is not domestic resident persons, but foreigners to whom foreign tax credit is offered.

As it has been to date only the UK that has concluded bank levy treaties, and only with France and Germany, the following discussion is confined to these three jurisdictions. It is useful to see the legal sources both at national and international level. Table 2 is reproduced on them.

13 Matheson, Th.: Financial Sector Taxation and the Ongoing Financial Crisis. Amsterdam Centre for Tax Law Conference, December 9, 2011. 
Table 2: Current legal status

\begin{tabular}{|l|l|l|l|}
\hline & UK & France & Germany \\
\hline $\begin{array}{l}\text { Current status of } \\
\text { legislation }\end{array}$ & Legislation included in & Enacted on December & Relevant legislation \\
the UK Finance Bill & 15,2010 together with & introducing the bank \\
published on March 31, & the Finance Act for & levy was resolved on \\
2011 and due to pass & 2011. Effective as of & December 9, 2010 and \\
into law in the summer \\
of 2011, but legislation \\
is effective from & January 1, 2011. & & December 31, 2010. \\
& January 1, 2011. & & \\
\hline
\end{tabular}

Notably, the German operating branches of foreign financial enterprises may escape German taxation as they come from a country of the European Economic Arena ("EEA"), and due to the European passport, according to which they are not subject to bank licensing in Germany. As well, a UK subsidiary of a German bank falls out of the scope of German taxation because Germany applies a bank levy to single entities only. The German operating permanent establishment ("PE") of a UK bank will certainly not be taxed in Germany. The reason for this is that the UK-Germany double bank levy convention explicitly provides for that.

Interestingly, the levies are applied in the three jurisdictions under discussion precisely to address externalities. The financial activity that seems to suggest less risks may be excluded from taxation, and progression in tax rates refers to dangers of expansion. It is also noteworthy that consolidation applies on the widest scale in the UK. France also applies its levy on consolidated entities, provided, however, that the head of group operates in France (as mentioned). Germany applies its levy on single entities. Notably, Germany does not give relief from double charging because the German levy does not deem to be a tax. This is not really logical because all the relevant counties concluding double bank levy conventions are aware of the bank levy that is different from normal taxes.

In a case where a UK bank is owned by a UK non-bank, the UK regulations are not consistent with the rule of the UK-France treaty on the primary taxation power of the origin country. Accordingly, the UK renounces taxing the entities that are established in the UK. One can still argue that in a case where a UK bank is under the control of a UK non-bank, both the UK bank and the UK non-bank fall outside the scope of the logic of bank levy regulations.

It is likely that in a case of mixed control, the respective double charging convention does not provide relief from double burden. The German subsidiary of a UK bank that is ultimately owned by a German bank may be subject to the German levy, being an entity ultimately owned by a German entity. However, the same entity may simultaneously be subject to the UK levy. This is because it is directly owned by a UK bank. Relief from double taxation may fail if the public authorities of both jurisdictions argue that the respective entity falls under their own authority.

The double bank levy conventions as examined above, largely follow the structure of an income tax treaty, based on the OECD model. However, the allocation of taxation power is different from this, as discussed. The UK-Germany treaty has special rules, as already mentioned above. This is first because Germany respects in its law on bank levy the single European system of licensing financial enterprises, while the UK does not seem to do the same. Second, Germany applies its bank levy on single entities. This is why a subsidiary of 
a German entity that has been established in the UK falls out of the scope of German regulation. Table 3 follows to illustrate what has been dealt with above.

Table 3: UK-Germany double bank levy convention, compared to the OECD model income tax convention

\begin{tabular}{|l|l|}
\hline $\begin{array}{l}\text { UK-Germany convention on the avoidance of double charging of } \\
\text { bank levies }\end{array}$ & $\begin{array}{l}\text { OECD model income tax } \\
\text { treaty }\end{array}$ \\
\hline Art. 1 on banks as covered, possibly on a consolidated basis & Art. 1 on the personal scope \\
\hline Art. 2 on bank levies, aimed at reducing systemic risk, as covered & Art. 2 on the taxes covered \\
\hline Art. 3 on definitions & Art. 3 on definitions \\
\hline Art. 4 on residence & Art. 4 on residence \\
\hline Art. 5 on permanent establishments & $\begin{array}{l}\text { Art. 5 on permanent } \\
\text { establishments }\end{array}$ \\
\hline $\begin{array}{l}\text { Art. } 6 \text { on charging rights on permanent establishments: the primary } \\
\text { taxation power rests with the state of residence, even on a consolidated } \\
\text { basis }\end{array}$ & $\begin{array}{l}\text { Art. 7 on business profit: the } \\
\text { primary taxation power rests } \\
\text { with the state of source }\end{array}$ \\
\hline
\end{tabular}

\begin{tabular}{|c|c|}
\hline $\begin{array}{l}\text { UK-Germany convention on the avoidance of double charging of } \\
\text { bank levies }\end{array}$ & $\begin{array}{l}\text { OECD model income tax } \\
\text { treaty }\end{array}$ \\
\hline $\begin{array}{l}\text { Art. } 7 \text { on the elimination of double charging: } \\
\text { - the UK levy is credited against the German levy in respect of the } \\
\text { German operating subsidiary of a UK parent in a banking group } \\
\text { - the German operating PE of a UK bank is exempt from the German } \\
\text { levy } \\
\text { - the German levy is to be credited against the UK levy in respect of a } \\
\text { UK operating subsidiary of a German parent in a banking group (under } \\
\text { German national law, no German levy on the UK operating subsidiary } \\
\text { of a German bank) } \\
\text { - the German levy is credited against the UK levy in respect of a UK } \\
\text { operating PE of a German bank }\end{array}$ & $\begin{array}{l}\text { Art. } 23 \mathrm{~A} \text { and } 23 \mathrm{~B} \text { on the } \\
\text { elimination of double taxation }\end{array}$ \\
\hline- & Art. 24 on non-discrimination \\
\hline Art. 8 on MAP & Art. 25 on MAP \\
\hline Art. 9 on the exchange of information & $\begin{array}{l}\text { Art. } 26 \text { on the exchange of } \\
\text { information }\end{array}$ \\
\hline
\end{tabular}

Double levy conventions are different from income tax treaties at three major points:

- such a convention applies to levies that are usually calculated on a consolidated basis;

- such a convention applies to levies that are aimed at reducing systemic risk; and

- the primary power of taxation rests with the country of origin.

Apparently, both the subjective and objective scope of a double levy convention is significantly different from that of an income tax treaty. This is the basis, on which it can be explained why such a treaty is different from an income tax treaty as to the allocation of taxation rights as well. The latter is only the corollary of the former. Deviation from the 
normal taxation standards can eventually be traced back to the function and character of a bank leverage tax that is fundamentally different from normal taxes.

The externalities arise from the financial crisis that appears globally. The various countries have largely remained to date to handle with it, however, at a national level. This makes also restriction on the cooperation with other states concerning the allocation of taxation power. This is why the allocation of taxation power is much more limited in case of double levy conventions than in case of income tax treaties. In the latter instance, the function of fund raising need not be associated with the function of addressing externalities. This is thus a situation that can be managed in a much easier way.

\section{Justification issues}

\section{(i) Tax incidence}

Article 12 of the proposed FTT Directive provides for that no taxes can be introduced at a national level that would be compatible with the European-wide FTT. This is because a tax, being in competition with FTT, would disturb the smooth operation of the European FTT. It was also necessary to clarify the relationship with the consolidated EC Capital Duty Directive $(08 / 7 / \mathrm{EC})^{14}$ and the consolidated EC VAT Directive $(06 / 112 / \mathrm{EC}) .{ }^{15}$ Namely, the VAT Directive also prohibits the introduction of domestic taxes that would be compatible with the harmonised value added tax. Similarly, the Capital Duty Directive does not allow to introduce domestically taxes on the issue of securities. Since the European FTT would be compatible at least with the Capital Duty Directive, it is necessary to provide for that the FTT Directive does not prejudice the existing provisions of the Capital Duty Directive.

FTT concerns the trade in securities, including derivatives. The FTT Directive excludes from its scope among other things the daily transactions of lending and payment. Notably, Hungary has recently adopted a tax on the transactions of daily payments. In principle, it would not disturb the operation of FTT. Currently, BLT and securities transaction taxes have been in effect in some Member States. BLT would only be comparable to FTT if it were considered as a tax, the burden of which could be passed over. Since this is not precluded, BLT may be affected by the said Article 12, although this in not likely. However, it is difficult to predict what economic impact the simultaneous application of domestic BLT and the would-be European FTT would have.

Knowingly, the basic options that are available for the taxation of the financial sector are: FSC or BLT (steering duties), FCRF (a fee-based charge), FTT (Tobin tax), FAT (taxation of the value added), and claw back (ex post) measures. BLT and FTT certainly raise the problem of tax incidence. As one can hardly imagine that a steering duty applicable to the financial sector would insulate private households and ordinary businesses from the impact on them of these taxes, the question of economic incidence cannot be avoided. The result should be at least that the new tax burden may mean higher borrowing costs and lower saving rates. ${ }^{16}$

14 OJ L 46, 21.02.08, 11.

15 OJ L 347, 11.12.06, 1.

16 Vella, J.: The financial transaction tax debate: Some questionable claims. Intereconomics, $2012(2), 90$. 
The problem of incidence does not only mean that taxes fall upon a wide group of market players, but also that taxation may be applied so widely that the various types of public charges may overlap with each other. In case of a fee, tax incidence is no problem. Even justification is directly available if reference is made to a possible equivalence to be achieved between the liability of payment and the provision of public services. It is only a question here who would be the beneficiary of these services. In case of FAT (e.g. in case of a profit-based tax), the burden of tax, being of direct nature, surely cannot be passed over. So, it is easy to determine whom taxation falls upon.

In case of BLT and FTT, it is an issue whether the burden of tax can be passed over. It is still not precluded either that the taxation power is simultaneously established on both the personal and territorial scope of taxation. This is not usual in case of taxes, the burden of which can be passed over. The result of the scope of taxation is that, upon the levy of tax, both unrestricted and restricted tax liabilities occur, connected to both the origin-based and destination-based scope of taxation.

It can thus happen that worldwide taxation is introduced even in case of transactions. Not easily, but one can find examples for this. See in this respect the taxation of gratuitous transfers (whether "inter vivos" or "mortis causa"). In many jurisdictions, property transfer taxes are established on worldwide taxation. For the taxation of transactions, it is yet normal that the scope of taxation is confined to the legally interpretable place where the taxable transaction is carried out.

In case of BLT, it comes from the simultaneous presence of the possible pass over of the tax burden and the introduction of worldwide taxation that the broadening of the liability of tax payment is subject to particular justification. It is in particular conspicuous how large the scope of the proposed European FTT is, although FTT is clearly a transaction-based tax. In case of BLT, it is not as much clear what is the subject of tax. It may vary, depending on whether the total balance sheet assets or liabilities are taxed, or what items will be excluded from the scope of taxation. It is furthermore not clear either whether the burden of tax could be really passed over. The widely designed scope of taxation may, however, lead to problems like double charging (taxing both on the foreign-operating branches of domestic enterprises and the domestic-operating branches of foreign-resident enterprises).

It is a question, indeed, what is BLT levied on. Probably it is different from a transaction-based tax. It cannot be simply considered as a net wealth tax either even if the tax is levied on the total balance sheet assets (whether on a risk-weighted basis or not). Being levied on liability items, BLT is not far from turnover-based taxes. This way, it can be seen as approximate to transaction-based taxes. It is a further problem if FTT and BLT are applied in parallel to each other. This has been to date the practice in a few countries (see, e.g. the UK stamp duty and the French FTT in parallel to the UK and French bank levies, respectively). If overlapping in taxation cannot be excluded at a national level, it is even a more serious issue to meet the possible introduction of taxes at a European level.

With FTT, it is a problem of tax incidence that the taxpayer position is determined in line with the fundamental Community freedoms, including not only the freedom to open a branch in another Member State, but also the freedom to supply services across the border. As a consequence, a party not locating in an FTT zone may be caught by taxation on the basis that he or she is a party to a transaction, the other party to which resides in an FTT 
zone jurisdiction. Then, the first party may be obliged to register for FTT purposes in the affected FTT-zone country, although he or she is not resident in that country. ${ }^{17}$

With BLT, it is problematic for the purposes of tax incidence that consolidation applies. Consolidation cannot be avoided because the bank levy is introduced in line with the banking regulations on capital adequacy. Tax design is adjustable to the banking law framework that has already been made when bank levy is to be introduced. Financial law regulation does not make any sense unless it is based on consolidation. Consolidation is a challenge both for the company and tax lawyer, however, because the unit of regulation does not coincide longer with a legal entity. The entity subject to financial law regulations is thus different from the entity subject to company or tax law provisions. As a result of consolidation, a foreign resident subsidiary is subject to taxation in the country where the head of group is resident. This is for tax purposes a situation that can hardly be managed unless a new concept of deeming rules is introduced.

The French bank levy legislation seems to be logical in the instance that a non-French resident subsidiary only falls within the scope of French taxation if it belongs to a group, the head of which is resident in France. The UK does not apply such a distinction. However, in the UK, the scope of taxation is restricted in case of the UK-resident subsidiaries of foreign-resident parent companies insofar as the UK operating foreign subsidiaries do not fall within the UK taxation unless they belong to a UK banking group. In France or in Germany, there is no such restriction in effect. Consequently, once a subsidiary is established under the respective national law, it is automatically caught by the national bank levy. Notably, consolidation is obviously more digestible in the UK than in a continental jurisdiction both in positive and negative directions because it has been deeply integrated in the business and accounting practice as well.

\section{(ii) Handling market imperfections}

As discussed, the working papers of both the IMF and the European Commission can be criticised on the ground that they do not clearly depart themselves from the false presupposition that markets would tend to equilibrium and departure from it would be at random only. They do not utter either that financial hyper activity is socially useless. The justification of either FTT or BLT is to be established on the argument, however, that the externalities to be addressed by taxation are to be removed. These papers are thus not pleased with the only reference to the proper functioning of the internal market. They have been prepared, based on a shift in paradigm: the issue to be tackled is no longer what are the restrictions the Member States may apply on the proper functioning of the internal market. They focus instead on the externalities arising from the financial crisis. They suggest that the internal market may cease to operate properly even for lack of distorting measures to be taken by Member States. In other words, market imperfections are implicitly recognised. This is the likely reason of the tax design with an extremely wide scope of taxation.

From the angle of economic criticism, tax incidence does not seem to be a very serious issue. From such a perspective, the danger of relocation should not be exaggerated. This is because market participants would stick to the network facilities of the London and Frankfurt stock exchanges. ${ }^{18}$ It could thus be not easy for them to escape taxation. The

17 Obouforibo, B. R.: A legal analysis of the proposed EU financial transaction tax (manuscript). Amsterdam, 2012. 21.

18 Schulmeister-Schratzenstaller-Picek: A General Financial Transaction Tax Motives. op. cit. 3. 
cascade effect of tax could also be taken away, as long as FTT and BLT would not typically apply to a chain of value-added generating transactions. Instead, they would allegedly be applicable on a long line of bets to be independent from each other. ${ }^{19}$

From a business perspective, the problems of the cascade effect or the allegedly low rate of taxation cannot be eliminated. Truly, a long line to bets can be identified that are independent of each other. There are other structures in capital markets as well, however. Not to mention about mere speculation, there can be market players, like retail asset managers, pension funds or investment funds, whose transactions are integrated in the respective market segment. They are not in a position of avoiding getting engaged in a series of transactions.

The rate of tax is a question again that can be studied from different angles. The tax rate can be compared not only to the notional value of the underlying transaction, but, e.g. to the sum of the option fee payable. Then, in particular if the fee payable is low, one can conclude that the effective tax rate is not-let us say- $0.1 \%$, but $3 \%$, or even $20 \%$, depending on a case. ${ }^{20}$

One has also to tackle the problem of regression that is built in the application of FTT or BLT. The taxes that are applied to transactions or liabilities, being of objective nature, are not sensible to the ability-to-pay of single taxpayers. In particular, small investors do not prefer the introduction of these taxes at a significant rate. This may also raise the problem of how to legitimise during a process of political decision-making the introduction of the new taxes in the financial sector. ${ }^{21}$ Although it is reasonable to apply such taxes to address systemic risks relevant to the operation of the financial sector, they would debilitate the redistributive function of taxation. This is clearly a particular constraint on the application of these taxes that must not be taken out of consideration.

Financial regulation as an alternative to financial taxation usually has progressive impact. For example, the introduction of bans on certain exposures would hit large investors much stronger than small ones. Regulation may thus be beneficial for the purposes of the redistributive effect of fiscal policy. ${ }^{22}$ It may significantly distort, however, the decisionmaking of the major financial service-providers.

The primary instrument of addressing systemic risks is regulation. Corrective taxation plays a complementary role only in this respect. This is due to the measurement bias that is extremely high if taxation applies. Regulation is less subject to a problem of measuring toxic instruments. ${ }^{23}$ This does not mean that measurement bias would undermine the applicability of corrective taxes in the financial sector. This means, however, that due to this problem the rationale for corrective taxes in the financial sector is in this respect rather disputable.

Apart from the above concerns, it is a major benefit of taxation that, contrary to regulations, it does not mean direct interference with the decision-making of economic operators. This may enhance the normative nature of a legal policy. This is an advantage despite the problems of regression in taxation and the measurement bias.

19 Op. cit. 5-6.

20 Vella: op. cit. 92.

${ }^{21}$ Masciarando, D.-Passarelli, F.: The financial transaction tax: A political economy view. Intereconomics, 2012 (2), 96.

22 Op. cit. 97.

23 Op. cit. 98. 


\section{(iii) Erosion of Community freedoms}

Fundamental Community freedoms are in the very heart of Community law. They constitute in fact tabu. Although they can be restricted, restriction can be only justified by the rule of reason, and even in that case provided that restrictions are introduced in the public interest, and that the restrictive measures do not violate the principle on proportionality. Having experienced the global financial crisis, the international agencies have started thinking over the tax policy options like FSC and BLT, and FTT. It is extremely difficult to introduce such taxes as they deem to be path-breaking measures in the sense that they cannot be justified longer with the idea of free competition.

Free competition is not sufficient longer in justifying new policy measures, including tax measures. The idea of free competition, on which the whole system of Community law is established, has become dubious from the perspective of both economic and social rationality, and morality. The financial crisis has thus entailed a crisis in legitimation. Once justification of new measures cannot be traced back to the idea of free competition, it is not clear longer what can be the basis for justification. No one wishes to forego the mechanisms of free trade, or the basic values of subsidiarity and private property. However, the introduction of financial taxes cannot be explained by these ideas. In other words, they can hardly be introduced in a way that they are entirely consistent with the fundamental freedoms. They can be justified, but not by the morality and inherent logic that come from the fundamental EC freedoms, and from the rationale of free competition that stands behind them.

The introduction of financial taxes may legitimately represent serious restrictions on the free movement of capital at least. The key issue of justification is in this respect whether the taxes to be introduced in their specific form go beyond what is necessary, while seeking to achieve the objective of stopping financial hyperactivity that may represent systemic risks on the whole economy of the Member States. Justification is dubious because it cannot rely on the normal argumentation that approximation of the existing practices of the Member States is necessary for the purposes of the smooth operation of the internal market. There should be existing rules, at which approximation could be targeted. Such rules do not exist, however, in the field of the taxation of the financial sector.

Article 113 TFEU is the basis for the approximation of the tax laws of Member States. Although it concerns indirect taxes, this does not mean that its scope is confined to a certain type of taxes. This is not only because it cannot eventually be clearly separated from each other the so-called indirect and direct taxes. It is more important that the operation of harmonised indirect taxes can be disturbed by any way of taxation. It is clear from the legal cases on the application of Article 33 of the Sixth VAT Directive that both direct and indirect taxes to be introduced at a Member State level are potentially suitable for disturbing the harmonised system of value added tax. ${ }^{24}$

It is still another question whether the meaning of Article 113 TFEU could be expanded to include not only the restrictive practices of the past, but also future obstacles to trade resulting from the development of national laws, as the Commission argues be referring to $\mathrm{C}-58 / 08 .{ }^{25}$ It is problematic in particular that obstacles to trade do not arise in case of the

24 Opinion of AG Chr. Stix-Hackl in C-475/03 Banca Popolare di Cremona, delivered on 14 March 2006, Paras 50-61.

25 Most often, "harmonisation" or "approximation" concerns existing national legislation. However, it is settled case-law of the Court of Justice that it can be used as a legal basis if the aim is 
financial taxes from the restrictive practices of Member States. Obstacles to trade have been generated by market imperfections. Article 113 is based on the assumption that there is perfection in the operation of markets. Distortion can be caused by the unilateral measures of the public authorities of Member States. This is clearly not the case concerning the innovated taxation of the financial sector. Distortions do not arise from state intervention, but from the very nature of the operation of financial markets. Member States are innocent in this respect. It would be naive to assume that the single European market remains to be free from imperfections when financial markets are failed. Without the applicability of Article 113 to the proposed FTT, a legitimate basis for intervention seems to be lacking, however. This may be equally true for BLT. If the ideal of fundamental freedoms and internal market, an elbowroom for free competition, is dubious, Community law harmonisation must inadvertently be overhauled.

\section{(iv) Constitutional background: looking for a balance in the allocation of privileges and immunities in a sphere of para fiscal charges}

The tax measures like FSC or FTT cannot be seen as common taxes. The function of raising funds is complemented by the function of addressing externalities. Tax and non-tax regulatory tools are in this respect closely connected with each other. Under the influence of financial regulations, tax legislation is deteriorated. First, financial law has to treat financial conglomerates, that is, groups of legal entities, and even on a scale of the globalised economy. Tax law can also manage groups through fiscal consolidation. The use of group relief cannot be taken for granted, however, and it is not extended, but in very few cases across the border.

Further on, financial regulations may be established on estimates, for example, in the field of introducing capital adequacy requirements or in the risk management associated with large exposures. The subject of taxation cannot be approximated by estimates, however. Even if the calculation of taxable profit is not strictly adjusted to single transactions (for example, where the profit of groups is divided by formulae), or the undistributed profit of controlled corporations is to be added to the parent's tax base in certain conditions), the liability to pay tax is to be determined at a level of exactness that cannot be satisfied by estimates. Tax liability cannot be based, e.g. on the assessment of how much risky portfolio investments or financial claims are.

A further problem is that financial regulations are to be flexible, being adjusted even to abrupt changes. Tax law cannot withstand much flexibility, however. It can be seen from the above that a bank levy-the product of financial rather than tax law-is far from being laid in place in the tax law order.

to prevent the emergence of future obstacles to trade resulting from multifarious development of national laws. The emergence of such obstacles must be likely and the measure in question must be designed to prevent them. See: Commission Staff Working Paper; Impact Assessment; Accompanying document to the Proposal for a Council Directive on a common system of financial transaction tax and amending Directive 2008/7/EC, Vol. 1, 28 September 2011, 23; C-58/08 Vodafone, O2, T-Mobile, Orange, ECR 2010, I-4999, Para. 69. 
Truly, tax law is artificial in the sense that it is based on the notion of income or profit. It is thus established on notions that have been artificially created by the legislator. ${ }^{26}$ In the reality of business, it is gross income (sales receipts) and costs that matter. Profit, being of synthetic nature, is merely the result of the comparison of the formerly mentioned two factors of business activity. Net income serving as a subject of taxation is artificial as well insofar as, under the concept of personal income tax, it is not identical to the gains or losses that are to be derived or sustained upon a single transaction. Instead, income is a positive margin, arising from the accretion of wealth that can be measured between two points of time. Tax law cannot still dispense with a normative basis. Tax liability must rely on legal provisions that determine tax liability preliminarily. BLT obviously fails to meet such a requirement. In this sense, it cannot be considered as a tax. Instead, it can be seen as a sort of para fiscal charges, introduced by the public.

In the current world of business, company and tax laws are losing their significance in many aspects. The participants of capital markets do not require complicated, comprehensive, categorical and rigid company legislation. They prefer to get rid of the compulsory choice of company law forms. They accept at the same time that the economic type, or rather the mere size of business is becoming relevant for the purposes of legislation. Important players of capital markets prefer to hold simple legal forms like partnerships that are fiscally transparent. These simple entities are still able to mobilise huge amounts of capital. This phenomenon can be called as the crisis of "anima societatis". The fate of tax law is similar. The exact determination of the taxable basis has been in many cases illusory. This is because the calculation of profit has become uncertain.

Para fiscal charges appear in an economic environment where manufacturing has been replaced by services, material goods have been losing their significance in contrast to the intangible goods, and the individual evaluation of the single assets and liabilities has been replaced by the evaluation of the earnings capacity of the business that occupies a particular segment in the market. This means that the valuation of assets and liabilities depends all the more on the subjective factor of holding a position by the business under evaluation as a carrier of particular earning capacity in the market.

As difficulties arise in measuring cardinal goods, relational goods become important. ${ }^{27}$ They are not subject longer to zero sum games like positional goods. Instead, the more they are shared, the more they are valuable. Due to the difficulties in measuring cardinal goods, distributive justice cannot be easily administered. This problem is even exacerbated by the crisis of the institutional system of welfare states. Systemic values are all the more replaced by improvisational interventions. The externalities that are associated with the financial crisis can hardly be put within the system of due process. Here, equality seems to be less important than to achieve a balance of the privileges and immunities that are allocated among market participants. As a corollary of the emerging privileges, public burden must also be borne increasingly. The more value financial service-providers raise, the more responsibility they have to assume. The burden that is laid on them should even be adjusted from time to time, and some times subsequently, because they operate in a changing environment.

${ }^{26}$ For the use of legal fictions in the context of tax avoidance, see: Deák, D.: A proposal of law and ethics and its application to the case of tax avoidance. In: Ove, J.-Lars, J.-Tynes, P. (eds): Responsibility, deep ecology and the self: Festschrift in honour of Knut J. Forlag 1, Oslo, 2011. 81-82.

27 Bruni, L.-Zamagni, S.: Civil economy; Efficiency, equity, public happiness. Bern, 2007, 179. 


\section{(v) Global crisis, debt bias and bank levy}

Tax law does not seem to be satisfied with the application of certain accounting measures. The acceleration in time of the realisation of gains or losses with notional contracts, the synthetic treatment of composite transactions with swaps, the calculation of gains or losses, based on fair valuation rules, and the application of the off balance sheet items seem to challenge the normative framework that is indispensable in tax legislation. Consolidation that is quite normal when the subjective scope of tax is drafted suggests again departures from the transaction-based methods of calculating profit or loss. The application of formulae upon the estimation of profit isolates the calculation of both accounting and tax profit from individual transactions. Instead, the gains or losses to be allocated among otherwise independent legal entities lack precision that has been normal to date in the sphere of accounting.

Besides, the current accounting practice seems to be inappropriate to handle the problem of debt bias. As mentioned above, a number of accounting tools are able to serve financial innovation without the possibility of signalling dangers. In particular, additional amounts of capital appear upon the restructuring of financial claims that does not mean fresh capital in financial terms, but in accounting records only. For example, new items of equity appear as a result of the exchange of shares. This is not new capital, however, that would have been raised by new investors. This is a change in the shape of investment only that suggests increase in capital, although the increase in capital is only the result of accounting operations. Similarly, the capital of the companies can be appreciated in line with accounting rules following mergers. It is not yet clear, however, how stable this appreciation will be, and how much the real economy can benefit from the changes arising from the accounting settlement. Precisely these problems led to the reform of accounting practices, the starting point of which was the Sarbanes-Oxley legislation.

The function of tax law is different from that of accounting. Tax law is not designed to give a clear view of the company's financial position, although it is useful for tax purposes as well to get a clear picture of business. Tax legislation-as a means of fiscal policy-is still designed to reflect the expectations of equity and legal certainty. These requirements may stop the management from carrying on activities that can otherwise be smoothly handled from an accounting point of view. Tax legislation-supporting the goals of economic stabilisation and distributive justice-suggests something extra, apart from accounting law.

Tax law is still dependent on accounting operations due to the link between accounting and tax profit (not to mention here how close this link can be in individual jurisdictions). Obviously, the tax legislator cannot isolate himself or herself from accounting manoeuvres. Although a business may be interested in presenting reduction in its assets and liabilities for tax purposes, it may act in a different way, while applying for new funds in the capital market. Tax and commercial accounting strategies may still overlap with each other in cases where improvement in the equity position is beneficial both for tax purposes and before investors. This will lead us again to the problem of debt bias.

Debt bias is a major reason for the distorting effect of taxation on business decisions. It has contributed to deepening the financial crisis as well. Therefore, methods like CBIT and $\mathrm{ACE}$ are welcome. They can complement existing thin capitalisation rules. The point to the notion of CBIT is that interest and similar expenses cannot be deducted. The impact of ACE is that the cost of holding equity can be recognised for tax purposes, similar to that of holding debt capital. By means of CBIT, the tax base can be increased. By way of ACE, the 
tax base is to be reduced. It is still common in the two measures that businesses may be discouraged from getting involved in financial hyperactivity.

A Tobin-like tax is also a means of discouraging businesses from getting engaged in financial hyperactivity. A transaction tax that is subtly targeted at the transactions deemed to be associated with externalities may be even more efficient than the income tax measures like CBIT or ACE. A bank leverage tax can also be efficient in discouraging business from financial hyperactivity. For example, there is progression in the rates of the German levy, depending on the type of risky liabilities. BLT is targeted in most jurisdictions at tainted business. In most countries that have introduced BLT, innocent assets or liabilities (longterm deposits, safe investments, etc.) are excluded from taxation, as discussed. Taxation may also be heavier, depending on the size of business.

It is a question whether income tax measures of CBIT or ACE and bank leverage taxes can be introduced simultaneously. Probably, this does not mean problems taken by itself since income tax measures are addressed to the asymmetry in the treatment of taxable income, and BLT or similar duties are in turn aimed at certain items of tainted assets or liabilities held by financial service-providers.

Richard Page acknowledges ${ }^{28}$ that BLT and a cost-of-equity tax deduction allowance would increase tax compliance costs, and would not generate a revenue flow that would significantly contribute to alleviating the budgetary imbalance problems. Furthermore, a BLT would also raise horizontal equity problems. They would not generate a long list of drawbacks associated with transaction taxes, however, he argues. Interestingly, transaction taxes would

- shift economic activity out of the jurisdiction, and generate deadweight losses;

- increase investment costs;

- decrease asset liquidity; and

- undermine the confidence in democracy by further incentivising the use of tax avoidance mechanisms that are not available to ordinary people.

Contrary to financial transaction taxes, BLT and ACE do not seem to be in a great need of being globally harmonised. Overlapping of taxation and asymmetries cannot be avoided, however, in case of BLT or ACE either. This is true, even if they do not hit taxpayers so directly as the case is with any contracting party providing services across the border that are subject to FTT.

FAT is another option of levying tax on the financial sector. In Denmark and in France, there are special payroll taxes as well. They are levied on the payroll of bank employees in proportion to the VAT exempt activity of the financial enterprise. The function of these taxes is to substitute for VAT that is not applicable to financial activity. The substitutes may suggest restrictions on the activity of financial enterprises. They also seem to avoid falling in the policy trap of transaction taxes. They are still not specific enough to meet financial hyperactivity. The problem of debt bias is not covered by FAT either.

28 Page, R. T.: Foolish Revenge or Shrewd Regulation? Financial-Industry Tax Law Reforms Proposed in the Wake of the Financial Crisis. Tulane Law Review, 85 (2010-2011), 213-214. 


\section{(vi) Double charging in conditions of emerging harmonised banking law and fragmented tax law}

Conditions for international cooperation are irritated if taxes are levied on a consolidated basis. Overlapping of the sovereign taxation powers can only be mitigated when those subsidiaries of foreign enterprises do not fall within the scope of domestic taxation that do not belong to a domestic group (like in the UK). Even in that case, the origin country is not willing to renounce levying taxes on the foreign operating branches and subsidiaries. This is because the legislative responsibility is concentrated both in the area of tax and non-tax regulatory tools in the country where the entities (or rather the groups) are established. As a consequence, the taxation power cannot be allocated to the destination country. This is a tendency that is not consistent with what is happening in the sphere of consumption taxes or income taxes. Even if international bank levy agreements can be concluded on the avoidance of double charging, the destination country does not gain access to significant taxation power.

In the world of taxation, territoriality is guiding to the division of taxation powers. This is a tendency that is being superseded by the regulation of banks. The latter is a sphere where it is becoming acceptable that it is the responsibility of the country, in which the particular financial enterprise is established, and home country jurisdiction is in many aspects accepted in host countries. In the EU, we have had the single licensing system of banks since decades. In the global arena, the Basle standards also suggest the approximation of home country jurisdictions. Tax law has not yet been ripe for this. However, being introduced in line with banking regulations, BLT corresponds to the logic of banking law both in domestic and cross-border cases. Bank levies cannot thus be put smoothly in the national tax system either in case of domestic or treaty law.

Banking law suggests challenges for the tax legislator. In particular, it would be reasonable to take over the single licensing system that would be applicable to financial intermediaries that operate in the European capital markets across the border as the withholding agents of the payment and information of tax. Foreign resident intermediaries should be allowed to act as paying agents in the Member State of the client, resident in a Member State, different from that of the intermediary. Then, the intermediary would not be obliged to employ local agents, in order to deliver to the local tax authorities information and to provide the payment of tax. Although such a proposal seems to be logical, the real life is far from being consistent with it. What remains in practice is fragmentation. This not only makes business more expensive, and more risky, but such fragmentation could not be upheld in the circumstances of a global financial crisis either.

\section{Major conclusions}

(i) Reflexivity in law to substitute for legal certainty

The viewpoints of the business, and the lawyer, on the one hand, and that of the militant representatives of macroeconomics seem to be in irreconcilable conflict with each other. It may be quite persuasive to break with the tabu of free trade from the viewpoint of macroeconomic criticism. Such a break would mean significant interference with business decisions, however, that may endanger the smooth operation of financial markets. Out-ofmarket intervention may also cause the problem that the normative basis for taxation is debilitated. Arguably, the antinomy experienced between the views of business and 
macroeconomics could be resolved on a case by case basis, provided that the reflexivity of law opens up opportunities for the parties involved in individual cases to find agreements with each other. The chances of parties may still depend on the evolving macroeconomic environment.

As bank leverage taxes, and similar para fiscal charges are designed not only to raise funds, but also to address externalities, they are not able to provide such a level of legal certainty as the law on normal taxes. As bank levies, and similar para fiscal charges may be subject to adjustment by way of "ex post" measures, they cannot be explained, based on the traditional principles of equality and legal certainty. Instead, they rely on the reflexivity of law. It comes from there that contracting out seems to be appropriate to replace the equality before the law, and the consistency and coherence of legal and non-legal values to be developed during a course of discourse may be ready to substitute for legal certainty.

\section{(ii) Seeking to handle the problem of debt bias by bank leverage taxation}

FTT is attacked in particular because of constituting obstacles to liquidity and because of the danger of relocation. These problems can be avoided by BLT (or FAT) that can be viable in particular if introduced simultaneously with some of the cost-of-equity deduction methods to be enforced in income tax law. The combined effect of this can be to mitigate debt bias. A bank levy is superior to a transaction tax insofar as, being levied on balance sheet items rather than on transactions, it does not directly lead to the increase in the cost of finance. Financial service-providers are given a leeway to be economic with the burden of tax. In contrast, being subject to a transaction tax, they do not have any option, but to shift it to customers.

\section{(iii) Faded legislative ideal of a market with fundamentally freedoms}

Financial taxes represent innovation in tax law. In the context of taxation and financial regulation, tax law is to be approximated to banking law. From a European perspective, it is problematic that banking law is much more harmonised than tax law. Tax law is still expected to keep pace with banking law. For the time being, European bank law, based on the single licensing system, and tax law, fragmented and broken into the separate jurisdictions of the Member States, are in glaring contrast to each other.

It is another difficulty that harmonisation should be based on the approximation of the existing rules of Member States. In the evolving area of financial taxes, such rules have not yet been developed, however. Furthermore, the hard core of European harmonisation is the smooth operation of the internal market that is based on free competition. The point to bank levies and other para fiscal charges applicable to the financial sector is, however, that they are designed precisely to encroach upon free competition that has produced imperfections in financial markets.

Arguably, financial taxes are to be aimed at removing the obstacles to the future trade in securities. Then, restoration of financial markets can be hoped. Free competition cannot serve as an ideal to be reached by legislation, however, insofar as market imperfections are reproduced and, therefore, financial markets cannot survive without the interference with them by out-of-economic means even in the future. 